\title{
Resale price maintenance for books in Germany and the European Union: a legal and economic analysis
}

Citation for published version (APA):

Backhaus, J. G., \& Hansen, R. (2000). Resale price maintenance for books in Germany and the European Union: a legal and economic analysis. METEOR, Maastricht University School of Business and Economics. METEOR Research Memorandum No. 021 https://doi.org/10.26481/umamet.2000021

Document status and date:

Published: 01/01/2000

DOI:

10.26481/umamet.2000021

Document Version:

Publisher's PDF, also known as Version of record

\section{Please check the document version of this publication:}

- A submitted manuscript is the version of the article upon submission and before peer-review. There can be important differences between the submitted version and the official published version of record.

People interested in the research are advised to contact the author for the final version of the publication, or visit the DOI to the publisher's website.

- The final author version and the galley proof are versions of the publication after peer review.

- The final published version features the final layout of the paper including the volume, issue and page numbers.

Link to publication

\footnotetext{
General rights rights.

- You may freely distribute the URL identifying the publication in the public portal. please follow below link for the End User Agreement:

www.umlib.nl/taverne-license

Take down policy

If you believe that this document breaches copyright please contact us at:

repository@maastrichtuniversity.nl

providing details and we will investigate your claim.
}

Copyright and moral rights for the publications made accessible in the public portal are retained by the authors and/or other copyright owners and it is a condition of accessing publications that users recognise and abide by the legal requirements associated with these

- Users may download and print one copy of any publication from the public portal for the purpose of private study or research.

- You may not further distribute the material or use it for any profit-making activity or commercial gain

If the publication is distributed under the terms of Article $25 \mathrm{fa}$ of the Dutch Copyright Act, indicated by the "Taverne" license above, 


\title{
Resale Price Maintenance for Books in Germany and the European Union: A Legal and Economic Analysis
}

\author{
Prof. Dr. Jürgen G. Backhaus \\ Maastricht University, AE \\ P.O. Box 616 \\ 6200 MD Maastricht \\ The Netherlands \\ tel: $+31-43-3883636$ \\ fax: $+31-43-3884878$
}

\author{
Dr. Reginald Hansen \\ Luxemburger Straße 426 \\ 50937 Cologne \\ Germany \\ tel: $+49-221-464950$ \\ fax: $+49-221-436205$
}

email: j.backhaus@algec.unimaas.nl

Paper to be published in

International Review of Law and Economics

"I fail to see how a regime that keeps book prices higher than they need to be promotes culture."

Commissioner designate Mario Monti

\begin{abstract}
T raditionally, in the German language area, the resale or end-sale price charged for new books in bookstores to the end customer has been a fixed or list price, observance of the list being enforced by the German Book Traders' Association (Börsenverein des deutschen Buchhandels). The association operates a complex system of rules governing book fairs, registration of copy rights, dispute resolution in the publishing industry, communication between authors, publishers, the book trade and the general public, training and continuous education of the more than 22,000 licensed booksellers and many others. Recently, the European Commission has rescinded a comfort letter and challenged the end price system operated in the German language area for more than a century. This move by the retiring commissioner for competition was, however, challenged in the commission's last meeting, and the issue has not yet been resolved. This paper, after an introduction, gives an in-depth review of the history and organisation of the German book trade. The end sale price maintenance rule is considered a part of a complex organisation governing this industry. Part two is devoted to the law and economics analysis, which is complicated by the problem lying at the heart of the battle over competencies, whether the end sale price maintenance is a matter primarily of competition or of cultural diversity. The paper concludes with a set of preliminary findings.
\end{abstract}

Key words: book price maintenance, cultural diversity, electronic book trade, re-import of books

JELcodes: K21, L14, Z10 


\section{Resale Price Maintenance for Books in Germany and the European Union: A Legal and Economic Analysis}

\section{Introduction}

List prices and end price maintenance agreements between producers and vendors are not uncommon in some industries. Typically, such agreements occur when a brand name needs to be protected by specific services for maintenance of the product, by large stocks of materials necessary for the use of the products or if particularly high skills are required for the service to the customer in relation to the product. While, for instance, in the United States it is not uncommon for booksellers to discount ${ }^{1}$, in the German language area there has traditionally been a book price maintenance binding the booksellers not to discount (except under very specific conditions). Since Germany as a cultural entity extends over several sovereign states of which two are members of the European Union, an issue of cross border traffic arises (between the Federal Republics of Austria and Germany), and a suit had been brought by the Austrian book chain "Libro-Amadeus" which signalled that it would rest its suit in exchange for one hundred German railroad station book stores. ${ }^{2}$ During the very last meeting of the European Commission under its president Jacques Santer, the Belgian Commissioner for Competition, Karel van Miert, had pushed for a measure to prohibit the German resale price maintenance agreements in honouring Libro-Amadeus' claim on the basis of an expert opinion by the London based research group EuropeMonitor. Due to strong opposition from some of his colleagues, he failed to receive the eleven commissioners' majority of the requisite vote. This was due in particular to the opposition from the Commissioner for Cultural Affairs, the Spaniard Marcelino Oreja who based his argument on article 151 of the Treaty of Amsterdam which re-affirms

\footnotetext{
${ }^{1}$ The arrival of the Internet book trade has brought additional turbulence to book prices. Amazon.com Inc. for one has started to offer $50 \%$ discounts on best selling books, where a best-seller is defined as being listed on the New York Times best-seller lists. (The use of that list has sparked an additional legal dispute that has been resolved in the following way: Amazon can use the copyrighted list in exchange for sharing sensitive sales data with the New York Times.)

Other sellers such as Barnesandnobel.com Inc. have kept book discounts very steady at the 20$40 \%$ level, and this also applies to Dalton with its real as opposed to virtual book stores.

See George Anders, "Amazon to Offer Discounts of 50\% on Popular Books", The Wall Street Journal Europe, May 17, 1999, p. 16.

2 Michael Naumann, "Was Bücher von Kartoffeln Unterscheidet", Welt am Sonntag, 29, 13.7.1999, p. 19 (The Difference between Potatoes and Books).
} 
that the commission has to respect the cultural differences of the various Member States. This issue is by no means a spurious one. During the formal interviews of the candidate commissioners under the designated commission president Romano Prodi, the designated commissioner for Competition, Mario Monti, re-affirmed and even strengthened his predecessor's position, granting however that for the German book trade there may be a cultural aspect of which he yet had to be convinced. On the other hand, the candidate from Luxembourg for cultural affairs, Viviane Reding, made the cultural issue with respect to the German book trade a major plank of her pitch, along with an emphasis on preserving minority languages in the different Member States. In the meantime, the German Book Traders Association and its Austrian counterpart have tried to come to an agreement largely patterned upon the French system based on the Lois Lang. While the Commission in a press release of 23 February 2000 reported that the German and Austrian book publishers have now accepted the Commission's position implying that the cross-border system of fixed prices will be replaced by separate but coordinated German and Austrian systems of fixed prices, the same press release also stated that the solution obtained was now fully supported by Ms Reding, the now Commissioner for Culture and Education. On the other hand, the Commission has also tried to enlist the support of the Swiss Cartel Authority. In principle, issues of cultural affairs in Switzerland rest with the cantonal authorities, only antitrust policy is a matter of the federal level. Hence, the same problem resurfaces for Switzerland that is also playing out in Germany. If the cultural issue is of at least significant importance, the antitrust aspects would likewise have to be dealt with at the level of the Länder, i.e. by the sixteen Länder antitrust authorities. Given these circumstances, a law and economics analysis of the effects and their desirability of the end price maintenance agreements in the German language book trade is by no means a straightforward affair. Typically in law and economics work we can safely assume that there is an aspect to a broader issue that can be reasonably claimed for economic analysis. In this particular case, however, disentangling the economic and cultural issues is the first major task for addressing the problem. The consultancy work of the EuroMonitor group had readily been criticised for not taking into account relevant features of the German language book trade. The researchers, who had ro command of German, were, of course, in a most peculiar position. The material on the German language book trade is totally locked into the German language. However, the organisation of the book trade has a long history and both are very complicated. Hence, a thorough 
description with a view towards economic analysis is needed before any standard analysis can be applied ${ }^{3}$. Accordingly, the background paper consists in an analytical description of the structure of the German book trade with a view to understanding the functional role of the end sale maintenance agreements.

That part of the analysis has five sections. The first section deals with the role of competition and the development of the German book trade. The second deals with the development of the current organisational structure of the German book trade. The third part is devoted to the cultural mission of the German book trade as an exception in EU competition law. Fourth we deal with the change of position in the European Directorate General on competition with respect to the German book trade. Finally, the fifth section of part I looks at the position of the German Book Trade Association with respect to the European Commission initiative.

In the second part of the paper, we are trying to lay the groundwork for a sensible law and economics analysis that takes the historical and organisational history of the German book trade seriously and looks at its specific role in the development and care for German literary culture. One part of that culture is, of course, science and scholarship, which is why we need to look at the scholarly publishers separately. Part two therefore starts with a brief history of one of these originally German based publishers and its role in the international community of science publishers. This adds an additional dimension to the problem of understanding competition and the institutional order in which such competition can take place with respect to the production, availability, and sale of books. The analysis in the second part yields a set of propositions which necessarily have to underlie any type of decision making on the part of the European Commission. In the conclusions, we summarise our major findings and identify work still to be done.

The focus of this paper is not an analysis of the structure of the German language book trade as such. It is hard to measure the impact of the current system of resale price maintenance on quantity and quality (including composition and cultural diversity) of book production, in particular since the sector is currently undergoing deep technological change. The question explored here is whether regulatory action on the

\footnotetext{
${ }^{3}$ Backhaus, Jürgen G. and Reginald Hansen, 1999.
} 
part of the European Commission can conceivably be welfare enhancing. The Commission lacks authority where the cultural identity of member states is involved. hence, it is important to explore whether the current structure of the German language book trade, of which the system of resale price maintenance is only a part and which has evolved over several centuries, is intertwined with the cultural identity of the German language literary institutions in such a way that a link can be established. It is immaterial in this context to provide quantitative data (such as the number of books published per head of the population) because first, such data do not capture quality characteristics and secondly, there is no apparent link between such data and the cultural institution of a particular people. ${ }^{4}$

\section{Part I}

The History and Organisation of the German Book Trade

The current debate about the end price maintenance for German language books has to be seen in the context of the larger organisation of the German book trade, which has to be looked upon as path dependent and therefore different from organisational structures that have developed in some (but not all) of the other Member States of the European Union. It is therefore sensible to look at this organisational history more closely.

\section{The Function of Competition and the Development of the German book trade}

Currently, the industry of book publishing, wholesaling and retailing, as well as readers' behaviour is undergoing deep technological change. This will likely lead to new forms of marketing and new forms of production and new forms of packaging of what we now refer to as a book. In this sense, it is likely that the current system of resale price maintenance as it has evolved in Germany over time, will undergo changes quite independent from action taken by the European Commission. After all, since the invention of technical printing, the German book trade has undergone various

\footnotetext{
${ }^{4}$ The respective figures are: per 1 million heads of the population: in the German language area, the number of books currently available is 8,323, in the United States and Great Britain, this number is clearly bel ow 5,771. For details please see Backhaus and Hansen, 1999.
} 
technical innovations which, although ultimately welfare enhancing, have sometimes taken some time to materialise due to social frictions that they caused.

When using the term book trade, we refer to the entire industry of media bound information, from the conception by the author and his surroundings (in either a corporate or a government) based working environment or in a home based industry in terms of a put out system to the ultimate consumer, including production, processing, distribution, consumption or use and storage. This industry is now facing several challenges, both technical and institutional. At the technical level, there is substantial uncertainty about the future of the book itself. There are some who believe that the book in its present form will disappear and be replaced by some type of an electronic file or site. There are, however, others who believe that the traditional book does have a future, side by side with new electronic media, files, sites, discs and the like. Secondly, next to the production and storage of the media involved, publishing itself is becoming a more and more international and integrated activity in the sense that publishing houses merge across borders and language barriers. Hence, the traditional book becomes part of a multi-media and multi-language product menu. This process is third facilitated (but not caused) by the common European market. Similar developments can be expected in the NAFTA and the MercoSur. In addition, the European Union has now challenged the traditional form of the German language area book trade which, as one of its significant features, has the rule of (contractually based) fixed end (as opposed to intermediate) book prices. This intervention is all the more surprising since fifth the traditional book trade is currently being replaced by a virtual book trade through the Internet. This development already poses a substantial challenge to the traditional bookstore. In Germany alone, there are about 2,000 independent bookstores and more than 20,000 licensed booksellers. ${ }^{5}$

\footnotetext{
${ }^{5}$ Book sellers are organized as a craft, i.e. there is an apprenticeship, the time of a journey man and the master. Although based on state regulations, the system is administered by the respective chamber of commerce which also handles the exams. The curriculum is a mixture of those of a librarian and those of a merchant (Kaufmann), both professions also being similarly regulated. There are no restrictions on entry, and wages of employed book sellers tend to be depressed; the same holds for incomes of self-employed book sellers. The profession tends to attract highly intrinsically motivated persons, it has traditionally served as a niche for political minorities and outsiders, notably when political freedom was endangered. This may partly explain why opposition to the European Commission's initiative has been so widespread and across party lines in Germany.
} 
Technological and social change has indeed not come easy to the German book publishing and processing industry in its history. To give one example. When the publisher F.A. Brockhaus, who stands today for the most important German encyclopaedia comparable to the Encyclopaedia Britannica in the English language world, a house that had been founded in Amsterdam in 1805 but moved to Leipzig, decided in 1826 to replace its three wooden book presses built in 1816 after the move by a newly developed much more efficient express press, the printers trained under presses with the wooden technology resisted bitterly. Actually, on September 4, 1830, a mob stormed the printing facility in order to destroy the express presses, their leaders indicating their belief that the new technology took away the livelihood of many workers. ${ }^{6}$

These luddites saw the technology as a menace to their own livelihood. Similarly today, the five joint elements outlined above are seen and experienced as endangering the livelihood of the more than 20,000 German booksellers and all those who depend on them; since booksellers traditionally tend to be an important multiplier in the political community, the issue should not be underestimated from the point of view of the political feasibility of this European Union initiative. It is from this point of view that we urge a thorough analysis including the entire spectrum of historical, cultural and economic issues.

As a consequence of her complex history, Germany has cultural institutions which are very different from those found in other countries that form part of the European Union. (See the detailed overview in Backhaus and Hansen 1999.) The book as a commodity appeared, of course, almost simultaneously with the Lutheran Reformation (started in 1517), and not surprisingly some of the first printed works were translated Bibles. However, that same event, the Reformation, ultimately led to the disastrous Thirty-Years' War which was concluded through three treaties in 1648. As a consequence, Germany had many fairly independent states making up the whole German empire, and hence it also had many capitals competing one with the other, very often in terms of cultural affairs. Censorship would be practised in some states but there were always exceptions of more lenient rulers, and hence sometimes very small states produced a blooming publishing landscape, such as the tiny Thuringian

\footnotetext{
${ }^{6}$ F.A. Brockhaus, "1805-1940. Aus der Arbeit von fünf Generationen", Zum Gutenberg-Jahr
} 
Duchy of Saxony-Hildburghausen, the capital of which i.e. Hildburghausen became a centre of publishing, also the site of the first German-language encyclopaedia. Since trade between these many centres of book publishing had to be facilitated, early on the German booksellers developed their own fair with its own rules, regulations, overseeing boards, etc., organising the biannual book fair originally in Leipzig which also has the main German central depository library. This non-state association, which is still in existence and organises the book fairs in Frankfurt and Leipzig on an annual basis now, also became a pioneer in establishing authors' property rights (copyrights). It is important to emphasise the non-state nature of this entity, as German culture due to German diversity in statehood could develop unified structures only apart and separate from state organisation.

This cultural peculiarity proved to be a big advantage during the reign of the national socialists, who could not break the stern independence of independent publishing houses despite their very best effort and hence failed in totally suppressing basic freedoms of expression, despite trying hard. ${ }^{7}$ From this point of view, it is not farfetched to emphasise the cultural aspect of the German book trade organisation over issues of simple models of competition. The current system is a grown pathdependent structure with a long history, and this history is deeply steeped in German culture. Any European decision will have to take notice of the priority of the cultural aspect over the competition aspect, hence the main question that has to be addressed is exactly that which Commissioner Monti raised; what is the connection between the cultural diversity of German book publishing due to its peculiar history-based organisation on the one hand and the end price maintenance agreements on the other?

\section{Part II}

At the heart of the German language area book price agreements lies the question as to whether the institution is primarily a cartel with the effect of reducing output and increasing prices, or whether it has primarily the effect of promoting cultural diversity. On the basis of the historical description of the organisational structure of the German

${ }^{7}$ On aspects of this policy see the essay on the Springer-Verlag, forthcoming in Businesslibrary Review. 
book trade, this section provides a preliminary economic analysis. In order to reflect the complex structure of the German book trade, six different stages of market interaction are being distinguished, and for each stage the question is asked whether an end to the book price agreements would lead to a price effect (either an increase or a decrease) or have some effect on cultural diversity. It should be mentioned from the outset that it is possible that the destruction of the agreements by the European Commission would lead to an ultimate increase in book prices in addition to an adverse effect on cultural diversity. In principle, three outcomes are possible. The policy change can lead to an increase, a decrease or no change at all; and two characteristics need to be observed, prices and cultural diversity. This yields in principle nine possible outcomes. Hence it is the purpose of this section to narrow down the nine possible outcomes for each of the six distinguished stages, hence yielding a total of twelve predictions, since for each stage, there are two variables (prices and cultural diversity) for which the likely outcome needs to be established.

The purpose of this exercise is straightforward. If the analysis yields the result that there are significant effects on cultural diversity (irrespective of the price effects), then the issue at hand is not simply a competence of the Competition Commissioner. It is important to emphasise at this point that a focused economic analysis not looking at the effects on cultural diversity is not sufficient for this project. ${ }^{8}$ Before one can look at the appropriate decision itself, it has to be established in which political realm and hence political competency the decision has to fall. Despite recent moves in Germany in establishing an office in the Chancellery, cultural affairs are a matter of the sixteen constituent states of the Federal Republic of Germany and cannot be claimed by the European Commission. In Austria, it is the federal government's responsibility, in Switzerland it is a cantonal prerogative, except for the possibility that the issue of the end price agreements is primarily and overridingly an economic matter. In that case, this Swiss antitrust agency would be responsible.

Next to the initiatives by the European Commission, the book trade in Germany (but not in Austria or Switzerland) is faced with the effects of a planned tax reform and the book trade worldwide may undergo deep change as a consequence of the emergence of the Internet and the possibility of printing on demand. Since the first electronic

\footnotetext{
${ }^{8}$ For such an analysis see Henning Stumpp, "Die Preisbindung für Verlagserzeugnisse: Wettbewerbsbeschränkung oder Regulierung zur Beseitigung von Marktunvollkommenheiten?" Baden Baden: Nomos 1999, pp. 2 and 6.
} 
publications have already appeared which are not derivatives of a traditional book, the impact of this electronic revolution on the book trade broadly conceived is largely uncertain. It is very likely that the traditional German book trade will be affected, but it is uncertain in which way. Many licensed book sellers have taken to an extensive use of the Internet already, and quite a few book stores, notably some in remote communities, derive a substantial part of their revenue from Internet sales. Under these circumstances, the timing of the European Commission's initiative complicates a thorough analysis of the long-term consequences of any considered change in the rules affecting the German language book trade. ${ }^{9}$

There are six stages or levels on which the analysis has to concentrate.

\section{Stage 1}

At the heart of every creative project leading to a published result there must be an idea and hence by necessity an author. The author may be embedded in a productive context such as a corporation, a governmental environment, a not-for-profit organisation or a private environment, since much creative work is still taking place in the traditional form of home-based production. ${ }^{10}$ The diversity of book and related media production implies that books are not homogenous products for which simple demand curves can be drawn. We rather have to think of singular products and unique processes and circumstances of production when a culturally diverse landscape of books is to be envisaged. This distinction, although difficult to quantify, is important for the issue at hand. It is, in principle, possible to manufacture a book or documentary on any conceivable topic according to certain guidelines. As soon as creativity is involved and discoveries need to be made, such manufacturing turns into a craft. For manufactured products, market demand can be projected beforehand. In order to put

\footnotetext{
${ }^{9}$ Strangely enough, the European Commission takes the deep technological change currently affecting the book trade worldwide as a reason for its intervention in the historically grown German structures. In support, it cites the 1997 decision of the British Restrictive Practices Court.

${ }^{10}$ Among the almost 80,000 (in 199777,900 ) titles produced in Germany, $12.2 \%$ are literary productions as such, $7.2 \%$ fall into the category of mathematics and the natural sciences, $7.2 \%$ to arts, music and sports, $5.7 \%$ to medicine, another $5.7 \%$ to economics and business, $5.4 \%$ are books for children and adolescents, 5.3\% cover law, 5\% religion, 4.9\% make up the important market for school books, another $4.9 \%$ are devoted to history, $4.6 \%$ to philosophy and psychology, $4.4 \%$ to languages, $4.2 \%$ are maps, 3.2\% geography and travel and yet the remainder of another $20.1 \%$ is spread over a large landscape of other areas of knowledgeand entertainment.
} 
out craftwork, entrepreneurial judgement is necessary and a personal relationship between the put out entrepreneur, i.e. the publisher and the author or team of authors of the craftwork in question. This is not only the case with fine literature, it is also the case with scholarly work, and this is why the large scholarly publishers have developed highly diversified company structures with many independently operating publishers within them.

As the demand cannot readily be established for any particular piece of craftwork, just for a particular style or area or discipline of scholarship according to its own criteria of quality, for each individual piece it is hard to ex ante calculate the demand and likely business success. It is an entire line of work which identifies a particular publishing venture which has its own market segment and therefore can be assessed for its value. In order to have some basis for calculation, a fixed price allows for a precise contract with the author, establishing royalties and some expectation on which to base the extension of work and effort. Likewise, the fixed end price allows for appropriations of budgets on the part of the publisher to each particular venture. In fact, the fixed end price results in a cross-subsidisation of less successful projects by more successful ones, where it is not known beforehand which project will be successful and which will be less so. If the end price were not fixed, the entire calculatory basis would change. Then, one would first have to establish the demand for a particular product (and not line or class of products), conceivably establishing the demand by appropriate marketing methods beforehand. Then, a manufacturing of such a product could take place and manufacturing authors would be recruited to fulfil the task. Those would be able to command high honoraria. The end result would be a smaller number of highly successful products with the downside that the large diversity of products would suffer. For the American market, this has been well documented for scholarly books, which have all but disappeared in entire subdisciplines. ${ }^{11}$

Interestingly enough, the end price agreements in the international financial literature are routinely referred to $\infty$ the Austro-German book cartel. A cartel in the broadest

\footnotetext{
${ }^{11}$ See William C. Dowling, "The Crisis in Scholarly Publishing: The Public Interest 129", 1997, pp. 23-37. The crisis is identified as "the drying up of resources for intensive studies of small but worthwhile subjects in favour of trend-driven publishing" (p. 23).
} 
sense can be defined as "a group of producers that acts collectively". ${ }^{12}$ Generally, the implication is that the collective action involves agreement upon a price with the effect of reducing output and increasing the price above the competitive level. As has become apparent by now, the end price agreements result in fixed prices but not in an output reduction. In addition, the agreements do not result in a uniform price; the individual publishers remain free to set their prices at whichever level they desire, and they compete among each other with both prices and the quality of their product or better, product lines. Hence, speaking of a cartel overextends the appropriate meaning of the economic term and does not add to clarity. In conclusion, we note that the book end price agreements do not eliminate price competition, but that they do have a cultural effect in that through cross subsidisation cultural diversity is being supported. This diversity implies that some books, the trend-driven publications may be priced higher, but that a large number of books will also be priced lower than otherwise they would be. The overall price effect is not an increase, and ending the agreements would therefore not result automatically in a decrease of the overall book price levels.

\section{Stage 2}

Next to the books and their derivatives, there is, of course, also the market for copyrights. Here the question arises as to whether the end price agreements affects the value of copyrights. Again, we have to look for both a possible price effect and a conceivable effect on cultural diversity, in this case a quantity effect (number of copyrights granted and protected). In this stage 2 , when we look at the relationship not between the publisher and the author but the question of how many books will be marketed (and hence copyrights requested), the only effect the end book price agreements have on these decisions is to add an element of certainty and hence allow for a better calculatory base. The price itself can be anything, it is one means of competition. Yet the price is a fixed one, not an uncertain figure oscillating over time and place. The better calculatory basis allows for a broader and longer catalogue of books, and hence there is, again, an impact on cultural diversity. There is no discernible price effect at this stage.

An unrelated issue, which has, however, had a potential impact on the two variables discussed so far, concerns the planned repeal of accelerated depreciation of books held

\footnotetext{
${ }^{12}$ See Robert S. Pindyck and Daniel L Rubinfeld, "Microeconomics" Upper-Saddle River: New
} 
in storage by publishers. Under the current system in the Federal Republic of Germany, books printed and put in storage can be depreciated rapidly and hence will show up as profit only once sold. This allows for large catalogues of books actually held in storage over very long periods of time. A traditional science publisher, for instance, proudly emphasises that every book published since 1945 is still available. (The company lost its entire stock of books and its archive during the last war.) This policy will be hard to continue if accelerated depreciation can no longer be applied. This would lead to shorter durations of storage, shorter catalogues and in this sense a dampening effect on cultural variety. Some selected titles would be kept in storage, and there would then likely be an upward price effect for those cases. However, it should be emphasised that this measure is in principle unrelated to the European Commission initiative, although it impacts in similar ways.

The remaining four stages can be largely seen as being driven by the interests of the consumer. Here we have to look consecutively at the wholesale stage, the retail sale stage, the household decisions involving consumption and the impact of government initiatives with respect to cultural diversity.

\section{Stage 3}

As a vital link between the several thousand book publishers with their almost 100,000 titles in German alone per year on the one hand and the more than 20,000 licensed booksellers in their more than 2,000 book shops senving a population of about a hundred million in the German language area, there is the vital link of the wholesalers. These can quickly locate hard-to-find books and publishers and have the desired items shipped to the requesting bookstore in a matter of a few days, sometimes just hours. This system is by far superior to anything one can experience outside the German trade area, for instance in the United States. Since their turnover is so much larger than that of any one bookstore, even large ones in choice locations, the wholesalers can also maintain very large stocks of books, up to substantial fractions of all the books in print, the most frequently demanded ones in substantial quantities. This system of wholesale intermediacy owes its existence to the very large number of titles and publishers involved and operates under the umbrella of the fixed end price on the basis of which the customer has already made a choice and commissions the provision

Jersey: Prentice Hall, 1998, p. 10. 
of the book. The end price contains information provided on the one hand by the publisher and on the other hand, together with the first volume of orders, by the customer. Both of these sources of information substantially facilitate the decisions of the wholesaler. If that fixed end price were no longer available, wholesalers would have to make their own guesses as to which books might be requested and with which frequency, and they would necessarily have to specialise in subject areas, such as the ones mentioned in the quantitative survey. That would lengthen the process between ordering the book and receiving it, which is so all-important for the consumer in the end of the chain. We can therefore see clearly that there is a connection between the end price and the extent of cultural diversity, with the end price primarily reducing transaction costs in the interest of speed and diversity. Instead of searching for the best price of any specific book, booksellers can search for the closest availability of a particular book quoting a fixed price to their customers. Some book will be more expensive to ship than others, some searches will take longer than others, but overall the cost minimisation can be done on the basis of the sales figures these wholesalers have and which guide their policies of how to stock and which channels of communication to maintain and use. Abolishing the end price agreements would have to lead to a substantial reorganisation of the wholesale book industry, some of these wholesalers would probably try to reach a segment of end customers bypassing the retailers. Such a move might bring price advantages to a select group of book users, institutional purchasers such as libraries come to mind, but retail presence in smaller locations would necessarily suffer.

\section{Stage 4}

Much of the current debate focuses on the future of the more than 20,000 licensed booksellers whose existence is seen as endangered by the Association of the German Book Trade. The connection between the end price agreements and the operation of these booksellers is not quite obvious for the outsider, but can be readily gleaned from the history and organisation of the book trade described above and the discussion of the first stages of the book trade in this section. The discussion needs to take its start by a clarification of terms. The retailers are not involved in a cartel designed to fix the price and reducing the input. They are not even involved in some kind of collective agreement, as many retailers fiercely compete with each other in local markets. Due to their large number and regulation of entry through a licensing system that requires 
schooling but not the demonstration of some need for a book store in a local area, each store is faced by the ready entry of local competitors and needs to compete by satisfying customers with their specific wishes. That requires obviously to have an attractive collection ready for the casual up-to-date reader who may not be a repeat customer; this would be the strategy, for instance, in an American airport. ${ }^{13}$ However, just serving up current novels and other similar literature would only at most cover 12 percent of the entire book market available. The local book store will try to cater to the wishes of the different professional groups, adding their various demands in the sciences, the arts, medical literature, business and economic literature, children's and books for the youths, law, religion, school books and the like, carefully adding segment upon segment of these various demands according to their local condition. In this way, it becomes clear that the competition between the booksellers can become fierce without even having to involve price competition. (Price competition does happen with respect to special occasions, remitted copies and the like.) By excluding price competition in the normal case, the large number of booksellers are forced into quantity and quality competition that can only be won if as large a spectrum as possible of the total available can be projected onto the local market. This is exactly what cultural diversity is about, and it is surprising to what detailed extent the training of booksellers (which regularly takes three years) focuses on skills not only in retail management and business practice, but notably in identifying and finding titles in many different areas of knowledge and expertise. The more precisely sometimes vaguely described books can be identified by the local bookseller, the more precise can be the order to the wholesaler and the more promptly can it be fulfilled. Here, these skills of identifying items that the bookseller cannot possibly know as such, but can locate by using the correct categories of research, pay off in winning the customers' order through expending beyond what can be in store. These skills of selling what cannot possibly be in store are emphasised in the training, hence the link between cultural diversity and the function of the bookseller as documented in the training regulations is unmistakably there. In addition, the end price agreements allow for a low transaction cost relationship between the retailer and the wholesaler in the interest of speed and diversity. We can therefore conclude that the end price

\footnotetext{
${ }^{13}$ The complaint against the German system was actually brought by a large Austrian chain, operating some 200 stores, mostly in railroad stations and generating total annual sales of DM 0.5 billion. This chain is comparable to operators at, for instance, American airports.
} 
agreement does fulfil an important role with respect to cultural diversity, removing it would have an adverse effect on this cultural diversity.

\section{Stage 5}

Cultural diversity can only be obtained if a book is not only purchased but also consumed. It is in this context that the question arises as to the relative importance of price and quality competition in the book trade. It is, of course, readily conceivable that price competition can be organised on the basis of such lists as the New York Times best-seller list with some twenty or even fifty titles that are readily identified by a large number of people. This we can see on the Internet and can expect to continue as a phenomenon. However, cultural diversity is not about fifty current books, but it is about the accumulated annual stream of some 100,000 books only in the German language area. The purpose is to keep this stream flowing and to have it available not only as a stream but also as the stock of the past streams of annual production. If it is primarily those books that require a substantial amount of time for their consumption that we are concerned with, the overriding concern is not the price paid for the book in the book store, it is the ease with which it can be obtained and the ease with which it can be consumed. The time involved here in terms of opportunity costs is easily worth ten, fifty, even a hundred times the price of the book in the local store. Yet herelies the catch. If there is no local store available and getting the book requires an annual ritual of travel to a major city, conceivably even in a foreign country, the cost of book acquisition even in the presence of price competition becomes an obstacle to cultural diversity. It is this implicit calculus of the efficient reader which points us to the relative irrelevance of price competition in this area as compared to diversity competition. We hence have to draw the conclusion again that cultural diversity is served by the end price maintenance agreements and an insistence on price competition will substantially reduce cultural diversity.

\section{Stage 6}

The final stage involves the regulatory environment and government options with respect to promoting cultural diversity. At present, the view prevails in the European Commission that cultural diversity is best promoted or at least not harmed by fierce price competition. We have seen by now that this view is hard to defend. However, even despite the strong relationship between non-price competition and cultural 
diversity demonstrated for the first five stages, it is conceivable that governments may resort to even more effective means to promote cultural diversity. For instance, the Allende government in 1971 resorted to a policy of putting a book into everybody's hand and opened bookstores with deeply discounted paperbacks bought on the international (Spanish) market. The entire Spanish classical literature was readily available, as was an impressive set of socialist tracts originally of many different persuasions. As so many similar such initiatives, this policy was short-lived because the supply of these rock-bottom paperbacks, even in such a large market as the Spanish language one is limited. More diversity would only have been added by freeing substantial foreign exchange reserves, as local publishers not only due to paper shortages but a general environment hostile to free and unhampered book publishing moved elsewhere or into specialised niches. The episode demonstrates the difficulty of policies in this area. If the price is used as a policy instrument and discounts are sought for government purposes, this can be sustained for stock but with more difficulty for new books to be generated. A different market is that of schoolbooks, which through the prescription immediately receive an inelastic demand curve and contain no element of cultural variety. Here, a bidding scheme involving the provision of a schoolbook together with a price quotation might allow a state committee to base a choice on both quality and price. Likewise, public libraries can be used as instruments to promote cultural diversity, and since they do not need the specific services of the book trade, the idea can be entertained to give them direct access to wholesalers and thereby win discounts. This practice does exist. Overall, however, the options for a more effective promotion of cultural diversity by a state agency are extremely limited. It appears that simply granting the exemption for the time honoured practice is the most attractive choice, given that cultural prerogatives are scattered over different levels of government in the German language area and given that the cultural element clearly overrides conceivable benefits had from price competition in the book trade.

\section{Conclusions}

In this paper on the organisation of the German book trade, it has been argued that the cultural and historical aspects of its organisation are by all means more important than the anti-trust aspects. By way of summary, we can offer the following table. Looking at the six different stages as identified in the production of books and other 
similar media of communication, the question is whether this peculiar organisation of resale price maintenance agreements has an impact on the end price and on cultural diversity. As the table shows, our argument has been that in each of the six stages, the impact of the agreements on cultural diversity is clearly positive. The impact on prices is irrelevant or nil in three of the stages identified, and it is (due to cross-subsidisation) undeterminable with different effects in opposite directions at the other three stages.

Table 1

\begin{tabular}{||l|c|c|c|c|c|c||}
\hline Stages & 1 & 2 & 3 & 4 & 5 & 6 \\
\hline price & \pm & $=$ & \pm & $=$ & $=$ & \pm \\
\hline cultural diversity & + & + & + & + & + & + \\
\hline
\end{tabular}

The price agreements have a positive/negative/ uncertain effect on prices/cultural variety. 


\section{Literature}

Albert, H., "Bemerkungen zur Wertproblematik", in: Schriftenreihe des Max-PlanckInstituts zur Erforschung von Wirtschaftssystemen, Jena 1998

Albert, H., "Nationalökonomie und Entscheidungslogik. Ökonomische Probleme in Soziologischer Perspektive", Neuwied 1967

Anders, George, "Amazon to Offer Discounts of 50\% on Popular Books", The Wall Street Lournal Europe, May 17, 1999, p. 16.

Backhaus, Jürgen G., "Springer-Verlag 1842-1999: A Review Essay", Business Library Review, forthcoming

Backhaus, Jürgen G. and Hansen, Reginald, "Die Streit um der Aufhebung der Buchpreisbindung in Deutschland", Working Paper, Maastricht University, 1999

Börsenverein des Deutschen Buchhandels e.V., Presseinformation

Börsenverein des Deutschen Buchhandels e.V., "Erwiderung der anmeldenden Verlage auf die Beschwerdepunkte der Europäischen Kommission gegen die grenzüberschreitende Preisbindung zwischen Deutschland und Österreich - Zusammenfassung", Sonderdruck zu dem Börsenblatt für den Deutschen Buchhandel, Nr. 54 vom 7. Juli 1998

Böhm, Franz, "Wettbewerb und Monopolkamp. Eine Untersuchung zur Frage des wirtschaftlichen Kampfrechts und zur Frage der rechtlichen Struktur der geltenden Wirtschaftsordnung", Berlin 1933

Brockhaus, F.A., "1805-1940. Aus der Arbeit von fünf Generationen", Zum GutenbergJahr 1940. F.A. Brockhaus, Leipzig, 1940, p. 14 and p. 67 f.

Bücher, Karl, "Der deutsche Buchhandel und die Wissenschaft", Denkschrift im Auftrage des Akademischen Schutzvereins, 3. A., Leipzig, 1904

Bücher, Karl, "Buchhandel und Wissenschaft. Eine Antwort", in: Jahrbücher für Nationalökonomie und Statistik, III. Folge, 26 Band, Jena, 1903, pp. 237 ff.

Dowling, William C., "The Crisis in Scholarly Publishing: The Public Interest 129", 1997, pp. 23-37

Ersch, J.S. and J.G. Gruber, (eds.), Allgemeine Encyclopädie der Wissenschaften und Künste in alphabetischer Folge von Schriftstellern bearbeitet, Dreizehnter Theil, Leipzig, 1824, darin Stichwort: Buchhandel

Estermann, Monika and Michael Knoche, (eds.), "Von Göschen bis Rowohlt. Beiträge zur Geschichte des deutschen Verlagswesens", Festschrift für Heinz Sarkowski zum 65. Geburtstag, Wiesbaden, 1990

Frankfurter Allgemeine Zeitung (FAZ) 
Goldfriedrich, Johann, "Geschichte des deutschen Buchhandels vom Westfälischen Frieden bis zum Beginn der klassischen Literaturperiode (1648-1740)", Leipzig, 1908

Goldfriedrich, Johann, "Geschichte des deutschen Buchhandels vom Beginn der klassischen Literaturperiode bis zum Beginn der Fremdherrschaft. (1740-1804)", Leipzig, 1909

Goldfriedrich, Johann, (ed.), "Aus den Briefen der Göschensammlung des Börsenvereins der Deutschen Buchhändler zu Leipzig", Leipzig, 1918

Goldfriedrich, Johann, "Denkschrift betreffend die Bearbeitung einer Geschichte des deutschen Buchhandels der neueren Zeit", Leipzig, 1904

Goldfriedrich, Johann, "Geschichte des deutschen Buchhandels vom Beginn der Fremdherrschaft bis zur Reform des Börsenvereins im neuen Deutschen Reiche. (1804-1889)", Leipzig, 1913

Hasbach, Wilhelm, "Untersuchungen über Adam Smith und die Entwicklung der politischen Ökonomie", Leipzig, 1891

Kapp, Friedrich, "Geschichte des deutschen Buchhandels bis in das siebzehnte Jahrhundert", Leipzig, 1986

Koch, C.F., "Allgemeines Landrecht für die Preußischen Staaten. Unter Andeutung der obsoleten oder aufgehobenen Vorschriften und Einschaltung der jüngeren noch geltenden Bestimmungen, mit Kommentar in Anmerkungen", 3. A. Berlin, 1856

Liefmann, Robert, "Der deutsche Buchhandel in der Kartellenquete, nebst Untersuchungen über seine Organisation und voraussichtliche Weiterbildung", in: Jahrbücher für Nationalökonomie und Statistik, III. Folge 28. Band, 1904, pp. 200 ff.

Meerhaeghe, M. van, "The Information Policy of the European Commission", Heft 4, Centre for the New Europe, CNE, Zelik, 1995

Meyer, Julius, "Conversations-Lexikon für die gebildeten Stände", 6. Bd. Hildburghausen, 1843, darin Stichwort: Buchhandel

Müller-Armack, A., "Wirtschaftslenkung und Marktwirtschaft", 2. A. Hamburg, 1948

Myrdal, G., "Das politische Element in der nationalökonomischen Doktrinbildung", Hannover, 1932

Naumann, Michael, "Was Bücher von Kartoffeln Unterscheidet", Welt am Sonntag, 29, 13.7.1999, p. 19 (The Difference between Potatoes and Books)

Pindyck, Robert S. and Daniel L Rubinfeld, "Microeconomics", Upper-Saddle River: New Jersey: Prentice Hall, 1998, p. 10 
Sarkowski, Heinz and Gustav Weiland Nachf. Enhundertfünfzig Jahre Buchhandel in Lübeck, 1845-1995, Lübeck, 1995

Sarkowski, Heinz, "Der Springer-Verlag. Stationen seiner Geschichte". Teil 1: 18421945, Berlin, 1992

Steinfeld, Th., "Die Marktheiligen. Van Miert plant letzten Schlag gegen die Buchpreisbindung", in: FAZ 10.6.99, p. 49

Stumpp, Henning, "Die Preisbindung für Verlagserzeugnisse: Wettbewerbsbeschränkung oder Regulierung zur Beseitigung von Marktunvollkommenheiten?" Baden Baden: Nomos 1999, pp. 2 and 6

Wissowa, Georg, "Buchhandel und Wissenschaft", in: Jahrbücher für Nationalökonomie und Statistik, II Folge 26. Band, 1903, p. 218

Zedler, Johann, H., "Großes-vollständiges Universal-Lexicon Aller Wissenschaften und Künste, welche bisher durch menschlichen Verstand und Witz erfunden und verbessert wurden", Halle und Leipzig, 1733, darin Stichworte: Buchführer und Buchhändler 